\title{
From Information to Knowledge: Business Intelligence Usage and Perspectives
}

\author{
Damir Ravlić \\ Federal ministry of Education and Science, Bosnia and Herzegovina
}

\section{Abstract}

A lack of quality data is one of the managing problems. It does not mean that they do not exist, but on the contrary, we are usually swamped with unnecessary information. The problem is how to extract the essential data for decision-making from the large amount of data. The data are the part of the organization's assets and, together with the capital and human resources, are an important part of the overall competitiveness. New technologies to support taking the correct and valid conclusions from the "enormous" amounts of data are created every day. Business intelligence and knowledge management are indispensable elements of successful business systems and public administration strategy. The concept of business intelligence or business information management is one of the modern systems that offered the possibility of a comprehensive and efficient usage of information. The concept of business information management also provides usage of the remaining collected data and converting them into useful information and knowledge. The information technology development in recent years provides the ability to store large amounts of information at lower costs, and people share their knowledge and jointly and interactively work at large distances. If we take into account the aspirations of Bosnia and Herzegovina toward accession to the EU, the concept of business intelligence is even more important as our systems can be connected with the systems at the European Union level, or the public administration interoperability in the European context can be achieved. Goal of the paper is to review the notion of business intelligence, and to assess the level of business intelligence usage in the public organizations in Bosnia and Herzegovina.

Keywords: business intelligence, information, knowledge, Bosnia and Herzegovina, public organizations

JEL classification: O31, D83

\section{Introduction}

Public administration entails a system of authorities, organizations and bodies, and an independent assemblage of jurisdictions, jobs and assignments, specifically connected and guided with the goal of application of the legal norms, organizational instruments, managing methods, processes and procedures in order to full fill the mandate of the elected government. The term "public service" implies to the services delivered from authorities of public administration (or public sector) to the citizens and economy (business subjects) (Radivojević et al., 2010).

Rationally organized and efficient administration is the base of launching state's development, democratic establishment, the governance of the law and ensuring the European life standards. With these terms, all citizens and economy subjects (domestic and foreign) can accomplish their rights and obligations in a fast and effective way, and create favourable ambience for domestic and foreign investments (Bublin, 2009). According to the Project on assessment of management 
in Bosnia and Herzegovina (European Stability Initiative ESI-2004) which is made, among other things, to assess more fully the constraints on positive decision-making at all levels of government in Bosnia and Herzegovina, one of the most important conclusions of this evaluation of management is incredible lack of reliable information in the field of public policy in almost all political areas. The Government of Bosnia and Herzegovina operates without a solid base of information about what is happening in society. The democratic process depends on the information. Policy makers need information about society in order to make effective policy choices. At the same time, citizens need information about the work of government, in order to hold it accountable for its actions. It is seen here the importance the knowledge management in the institutions of government. In modern integration processes important position occupies the economic statistics, as part of quantitative economics. Integration processes in the European Union further impose the need for internationally comparable statistical data and information related to the fields of industry, agriculture and foreign trade, as well as on the level of individual sectors, countries and different regions (Stević, 2013).

Quantitative economy is the basis for adequate planning, analysis and forecasting of variations of economic activities in the future and making business decisions, both for the company level, and at the level of the national economy.

Therefore, business intelligence has three features: (1) it is the process of collecting data and information which after appropriate treatment become "knowledge"; (2) it is focused on the information on future processes, events, actions or movements can be anticipated; (3) it is an instrument that has a full role in the decision making process (Javorović et al., 2007).

\section{Measuring the development of business intelligence and maturity of the knowledge management system}

Business intelligence, most authors consider as a process, since it consists of several activities that are carried out continually. Activities in this process can be grouped according to homogeneity, similarity or immediate dependency or conditionality, and thus grouped activities can be called functions.

Various authors differently identify the activities in the framework of the BI process i.e. functions or phases, that is a differently grouping of activities by the functions or phases of the Bl process. Cimeša (2000) describes the process of implementation of business intelligence through the following activities (1) planning; (2) the collection of relevant data and information; (3) verification, sorting and analysing data and information; (4) dissemination of the report, and (5) analysis of capabilities.

Bevanda (2003) explains the business intelligence capabilities a bit more complex: (1) data collection, (2) storage and access to data, (3) dimensional structuring of data, (4) synthesis of data, (5) development of a model, based on knowledge, experience and intuitions, (6) prediction models, (7) the verification of the model, (8) the sharing of knowledge, (9) scenario analysis, etc.

Analyzing the above mentioned activities of the various authors and their grouping in the function, selected groups of functions is defined (Klepić, 2006), which represents a set of indicators that will measure the development of business intelligence: 1.) Identify and define the key needs for $\mathrm{Bl}$; 2.)The collection of data and information; 3.) Rating reliability and usefulness of data and information; 4.) Analysis of collected and available data and information, 5.) Storing data and information; 6.) Distribution of data and information; 7.) Protection of data and information. According to Gartner (Harris, 2006) and Bosilj Vukšić et al. (2004) critical success factors include three key areas in KM: 1.) Strategy and goals (the company 
must strive to define the strategic goals for KM); 2.) Infrastructure: (includes technological applications, business processes, management tools, roles/responsibilities); 3.) The sources of knowledge (includes knowledge of workers, customers, business partners and competitors). Using the assessing model of maturity level of KMS, we can define six different states in which the organization may be located. The states of maturity of in KMS organization varies according to the level of understanding the importance of the strategy and goals of the KM, KM infrastructure development and understanding of the importance of sources of knowledge in the organization and its surroundings. The model for assessing the maturity of KMS includes states from 0 to 5, where each state represents more senior level of development of KM infrastructure, KM strategies and sources of knowledge from previous.

Table 1

Six (state) levels of maturity of knowledge management (according to Gartner)

LEVEL OF MATURITY

State 0 (Nonexistent)

State 1 (The initial)

State2(Repetitive)

The

State 3 (Defined)

State 3 (Defined)

State 4 (Managed)

\begin{tabular}{ll}
\hline & business processes. \\
& activities in of the company. Creating and \\
State 5 (Optimized) & managing intellectual capital of the company \\
& is a key strategic objective of the company. \\
& The company is managed with the knowledge \\
and intellectual property of the company.
\end{tabular}

Source: Harris (2006)

There are many discussions about differences between knowledge management and business intelligence. Gartner defines business intelligence as a set of technologies that collect and analyse data to improve decision-making. Intelligence is thereby defined as the detection and explanation of hidden, inherent or business 
relevant contexts in a large amount of business and economic data (Hameed, 2004). On the other hand, knowledge management is described as the process of finding, selecting, purifying, and presenting information in a way that enhances the understanding of employees in a particular area of interest. Knowledge management helps organizations to gain insight and understanding from their own experience (Hameed, 2004). It is easy to conclude that knowledge is an integral component of business intelligence and decision-making.

Convergence of business intelligence and knowledge management is in fact the integration of the concept of business intelligence, knowledge management, learning organization and intellectual capital (Cimeša, 2000).

Population over which the survey will be implemented is defined as a population of institutions of public administration of Bosnia and Herzegovina, which includes public administration at the state level and the entities of $\mathrm{FBiH}$ and $\mathrm{RS}$, and the Brcko District (ministries, administrative organizations and independent authorities).

The list of these establishments will be used as a sampling frame. The Federation of Bosnia and Herzegovina has 16 ministries; 3 independent federal authorities; 9 independent federal administrative organizations - a total of 28 (without the county level). At the level of the RS there are 16 ministries, 6 republican administrations, 25 republic administrative organizations - a total of 47. At the Bosnia and Herzegovina state level there are 9 ministries; 27 independent administrative organizations within the ministries - a total of 36.In the Brcko District there are 11 departments of the Government (whose leaders make up the Government of Brcko District); 3 offices within the public administration and 1 directorate - 15 altogether.According to the data it can be defined that the total number of public administration organizations which will be investigated is 126 (without the county level). The sampleis a part of the population for which data are collected on the basis of which the conclusions about the population can be made.This paper will be used as the design of the sample, a simple random sample, in which will be implemented equal probability of selection of the population into the sample, in which case the random number generator will be used.The planned size of the random sample is 70 , thus having a fraction choice of $55.11 \%$.

Scientific aims:

-Examine how the level of development of business intelligence in public organizations affects the level of maturity of the knowledge management system in the areas of strategy and objectives, by which the strategy and objectives are observed through the level of maturity of the objectives, level of maturity of information and level of maturity of organizing the knowledge management system

-To examine in what way the level of development of business intelligence in public organizations affects the level of maturity of the knowledge management system in the field of infrastructure maturity, where the maturity of infrastructure observed through the maturity of applications, the business processes maturity, the maturity of roles and responsibilities and maturity of management tools and the knowledge management systems.

- To examine in what way the level of development of business intelligence in public organizations affects the level of maturity of the knowledge management system in the field of knowledge resources, where the maturity of source area of knowledge is observed through the maturity of the teams, the maturity and sophistication of users and frequency of use of the knowledge management system. 
Operational aims:

- To examine the possibility of improving the maturity of knowledge management from the point of application of the methods of business intelligence, referring to the most famous formal methodology for introducing a system of knowledge management, and apply the improved model in the public administration.

- Demonstrate that today it is necessary to use methods of business intelligence to increase the efficiency of decision-making that is building quality management system knowledge, as in a classical company, and in public administration.

- To improve the quality of public administration services by increasing the level of maturity of the knowledge management system with the support of business intelligence tools.

The hypotheses of this study are:

$\mathrm{H1}$ : The level of development of business intelligence in public organizations significantly affects the level of maturity of the knowledge management system in the areas of strategy and objectives, where strategy and aims are observed through the level of maturity of the objectives, level of maturity of information and level of maturity of organizing the knowledge management system.

$\mathrm{H} 2$ : The level of development of business intelligence in public organizations significantly affects the level of maturity of the knowledge management system in the field of infrastructure maturity, where the maturity of infrastructure is observed through the maturity of applications, the maturity of the business processes, roles and responsibilities of the maturity and the maturity of management tools of the knowledge management system.

H3: The level of development of business intelligence in public organizations significantly affects the level of maturity of the knowledge management system in the field of knowledge resources, where the maturity of source area of knowledge is viewed through the maturity of the teams, the maturity and sophistication of users and frequency of use of the knowledge management system.

\section{Expected scientific and practical contribution of research}

-The scientific contribution of research

The conceptual contribution of the work will consist in: (1) the research of the role of state and its institutions in creating a competitive advantage, especially in terms of scientific and technological development, (2) analysis of the role of business intelligence in the public administration and (3) a description of the process of introducing a system of knowledge management with an emphasis on the knowledge society and measuring the maturity of knowledge management system. The empirical contribution of the work will consist in determining the level of development of business intelligence and level of maturity of the knowledge management system in public organizations of Bosnia and Herzegovina. In addition to the study I will identify the direction and strength of the relationship between the levels of development of business intelligence in the public organizations and the level of maturity of the knowledge management system in: (1) the area of strategy and objectives, (2) the maturity of the infrastructure and (3) sources of knowledge the knowledge management system.

The methodological contribution of the work will consist of developing the research instrument for measuring the development of business intelligence in the public administration and the use of Gartner's methodology (Harris, et al., 2006) to measure the maturity of knowledge management in public organizations of Bosnia and Herzegovina. Using Cronbach's alpha coefficient, the validity of certain 
dimensions of both questionnaires the population of public organizations of Bosnia and Herzegovina will be tested. The practical contribution of the research is to introduce the concept of a network of public administration in order to improve efficiency and service quality, and to achieve the interoperability of public administration in the European context, which is a precondition for the accession of Bosnia and Herzegovina to the European Union. The interoperability of the government bodies is essential for the sake of modernization and re-engineering working processes, that is the introduction of the process of organizational structure and framework for interoperability is a prerequisite that must be fulfilled for successful communication among users in the electronic administration. Networked knowledge is a prerequisite for better functioning of complex working environments such as the public administration which requires the application of methods of business intelligence and the knowledge management system. The purpose of a network management services are coordinated between the institutions, that is a process of inter-institutional connectivity for delivering a faster and more comprehensive services to citizens and businesses.

\section{Methodology}

Figure 1

Model of the impact of development of business intelligence onto the level of maturity of knowledge management

The level of development of The level of maturity development business intelligence of theknowledge management system

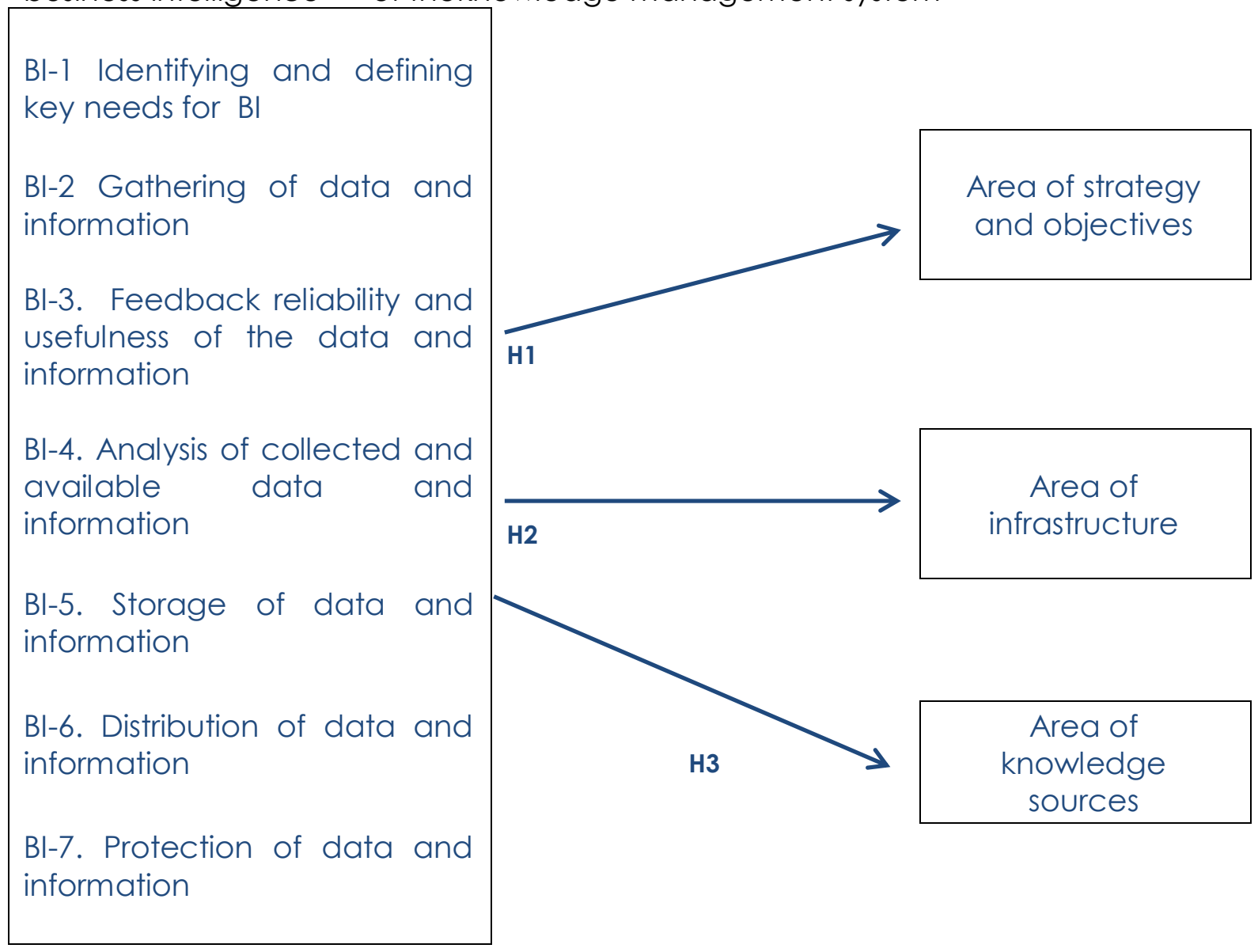

Source: Author's illustration 
In order to test the hypothesis of this study, it will be verified using Cronbach's alpha coefficient of reliability of common indicators of each dimension of business intelligence and the knowledge management system. In the case that the Cronbach's alpha is higher than 0.7, it is reasonable to use common indicators. If this proved to be justified, it shall be calculated on the following common indicators: For the dimensions of the development of business intelligence:

- Bl-1. Identifying and defining key needs for BI

- BI-2. Data collection and information

- BI-3. Rating reliability and usefulness of the data and information

- Bl-4 Analysis of collected and available data and information

- Bl-5 Storing data and information

- Bl-6 Distribution of data and information

- Bl-7 Data protection and information

For the dimensions of the level of maturity of the knowledge management system:

- CILJ-maturity objectives level of knowledge management

- INFORM - The level of maturity of information on the system of knowledge management

- ORG - The level of maturity of organizing the knowledge management system

- AP-level maturity applications

- PROC - level process maturity

- ULOG - The level of maturity of roles and responsibilities

- ALAT- The level of maturity management tools

- TIM - level of maturity teams

- $\mathrm{KOR}$ - The level of maturity among users

- SOFT - The level of sophistication and maturity of the frequency of use of the knowledge management system

Using common variables it shall calculate the linear regression models with common indicators of dimensions of knowledge management maturity as dependent variables and group indicators development of dimensions of business intelligence as independent variables.

\section{Discussion}

This work explains the set model of the impact of development of business intelligence to the level of maturity of knowledge management on the basis of which will be carried out exploration and proving the hypotheses, all in the aim of developing instruments for measuring these variables, which would enhance the existing models of measurement of development and maturity $\mathrm{BI}$ and $\mathrm{KM}$, which could affect the improvement of service quality of public administration in $\mathrm{BiH}$ and to achieve interoperability as one of the preconditions for the accession of $\mathrm{BiH}$ to $\mathrm{EU}$.

\section{Conclusion}

Restrictions:

-On Cross-sectional approach to research

-Orientation to only one country

Explanation: The primary studies will be carried out in a specific time period, which have the characteristics of cross-sectional studies. Therefore, the main limitation of this study arises from the characteristic data that represent a one-time snapshot of 
specific data, while not giving an insight into the long-lasting relationship and change. However, cross-sectional studies are widely used in the social sciences, due to high costs of longitudinal studies, which is the reason for application of this approach in the development of studies.

Guidelines for future research:

- A longitudinal research

- The orientation of several countries

- The panel regression analysis

\section{References}

1. Bevanda $\vee$. (2003), "Razvoj inteligentnih sustava korištenjem metoda za transformaciju podataka u poslovnu inteligenciju" ["The development of intelligent systems by using methods to transform data into business intelligence"], doctoral dissertation, Faculty of Economics, University of Mostar, Mostar.

2. Bosilj Vukšić V., Milanović Lj., Gombašek J. (2004), "Uloga informacijske tehnologije i drugih čimbenika u upravljanju znanjem" ["The role of information technology and other factors in knowledge management"], Faculty of Economics, University of Zagreb, Zagreb.

3. Bublin A. (2009), "Suvremena uprava" ["Modern administration"], Bemust, Sarajevo.

4. Cimeša M. (2000), "Integracija koncepcija Business Intelligence-a, upravljanja znanjima, učeće organizacije i intelektualnog kapitala" ["The integration of conceptions of Business Intelligence, knowledge management, learning organization and intellectual capital"], the report from the conference Business Intelligence 2000, The Institute for Business Research, Zagreb.

5. Hameed I. (2004), "Knowledge management and Business Intelligence: What is the difference?", available at: http://onlinebusiness.about.com/ (accessed June 25th 2015)

6. Harris K. (2006), "A Knowledge Management Maturity Model Explains Where You're Going and How to Get There", Gartner.

7. Javorović B., Bilandžić M. (2007), "Poslovne informacije i business intelligence" ["Business Information and business intelligence"], Golden marketing, Tehnička knjiga, Zagreb.

8. Klepić Z. (2006), "Utjecaj poslovne inteligencije na učinke poslovnih odluka top managementa" ["The impact of business intelligence on the effects of business decisions of top management"], doctoral dissertation, Faculty of Economics, University of Mostar, Mostar.

9. Radivojević M., Filipović Z., Kremenović O. (2012), "Od elektronskog poslovanja do poslovne inteligencije u javnoj upravi" ["From e-business to business intelligence in the public administration"], Official Gazette of the Republic of Srpska, Banja Luka.

10. Stević S. (2013), "Uloga i značaj ekonomske statistike U integracijskim procesima", Proceedings of the International Scientific Conference: "Pravni i ekonomski aspekti procesa integracije Bosne i Hercegovine u Europsku uniju" ["Legal and economic aspects of the process of integration of Bosnia and Herzegovina to the European Union"], Faculty of Law and Economy of Dzemal Bijedic University of Mostar, Mostar, pp. 134-141.

\section{About the author}

Damir Ravlić, MSc is a Senior Advisor for the area of development of scientific research and international scientific and technological cooperation. Author can be contacted at damir.ravlic@fmon.gov.ba 